\title{
Alternative Tourism in the Belitung Island with the Blue Tourism Concepts as the Effort to Achieve the Quality of Life, Quality of Opportunity and Quality of Experience
}

\author{
Devi Valeriani 1
}

\section{Rulyanti Susi Wardhani²}

\author{
Lecturer at Economic Faculty Bangka Belitung University 1,2 \\ Students at Economic Doctoral Program of Sriwijaya University 1,2; Email: devi.valeriani@yahoo.com
}

\section{Doi:10.5901/mjss.2015.v6n5s5p46}

\section{Abstract}

\begin{abstract}
All the natural maritime resources at Belitung Island is a major potential in tourism development. However, the concept of mass tourism which has been applied so far is not optimal to tourism development so it's not creating the competitiveness to attract the tourist. Therefore,that should be more effort so that the available resources are able to have competitiveness in attracting tourists visit. Blue tourism concept is a concept that emphasizes the beauty of the beach, the sea and the ecosystem that are expected to create opportunities for tourism and the subsequent impact on increasing the number of tourist's visit. The main purpose of this research is to provide a concept of blue-based tourism management tourism. Through a descriptive study using primary data through observation and interviews to the community, local government, tourists and also using SWOT analysis (Strength, Weakness, Opportunity, Threat), and GAP analysis has resulted a model of tourism development which is able to provide quality of life, quality of opportunity and quality of experience.
\end{abstract}

Keywords: Blue Tourism, SWOT Analysis, GAP Analysis, Tourist

\section{Introduction}

\subsection{The Relevance of the Problem}

Tourism is one of the most promising sectors for regional development. Along with its development, each region should have a different concept to other areas in tourist destinations. The desire of tourists who visited tourist destinations are starting to show a state where the majority of people looking for a better quality of traveled way of doing different interactions with the activities and culture of origin (Balquni, 2011). This is an opportunity for alternative tourism on the island of Belitung with blue build concept of tourism and environmental awareness / marine ecosystems. Donald VLMacheload (2006) argues that the concept of alternative tourism is very wide and varied. Of paper analyzed that the emergence of alternative tourism in response to the massive and mass tourist, "it seem modern Consumerism as a reaction, a counter cultural response to mass tourism". Belitung or Belitong is an island located in $107^{\circ} 31,5^{\prime}-108^{\circ} 1^{\prime}$ East Longitude and $2^{\circ} 31,5^{\prime}-3^{\circ} 6,5^{\prime}$ South latitude. This island is one of two large islands in the Province of Bangka Belitung Island, with an area of $4800 \mathrm{~km} 2$ or 480,010 hectare. Belitung Island consists of two districts, the first is Belitung with the capital district, Tanjung Pandan and East Belitung with its capital is Manggar. Natural attractions in Belitung and East Belitung recorded in the Depart of the Provincial Tourism Bangka Belitung Islands-are as follows:

Table 1. Potential tourism in Belitung Island

\begin{tabular}{|l|l|}
\hline Districts & Tourism Potentials \\
\hline Belitung & $\begin{array}{l}\text { Tanjung Tinggi Beach, Tanjung Kelayang Beach, Tanjung Pendam Beach, Pantai Tanjung Gembira, Pantai } \\
\text { Tanjung Kiras, Pantai Panyaeran. Pantai Mabai, Pantai Penyabong, Pantai Bukit Batu, Pulau Batu, Pulau } \\
\text { Lengkuas, Pulau Pasir, Pulau Burung, Pulau Kepayang }\end{array}$ \\
\hline Belitung Timur & Pantai Nyiur Melambai, Pantai Serdang, Pantai Burong Mandi, Bukit Batu \\
\hline
\end{tabular}

Source: Department of Culture and Tourism, Bangka Belitung Province 2014

From the data, it can be said that the Belitung Island is an island that has a huge potential to be developed as a tourist 
area with blue tourism concept. The main factor is the natural condition and the white sandy beach with rocks that look very natural, blue sea and the beautiful natural scenery. The current phenomenon in Belitung island, the tourist activites are enjoy the beauty of nature, bathing, surfing and other conventional activites. Attractions, souvenir products, culinary variety and attributes are still very limited. Ideally, the more number of tourist attractions and its products in a tourist attraction it will affect the value of interest in the tourism destination. It is possible that coastal tourisms on the Belitung island are more directed and planned to be developed by considering the three pillars of tourism development, namely economic, social, cultural and environmental but still brings the concept of blue tourism. Development of coastal tourism refers to the blue-tourism is the concept of marine tourism that similar to the concept of ecotourism, where tourists are invited to enjoy the beauty of nature while practicing conservation measures on the ecosystem around tourism, and gives tourists a wide choice of tourist attractions, not just a tourist attraction but in the conventional form of learning and preservation of the natural environment. Andriani (2011) asserts in his research that ecotourism is not just a journey, but a journey that is responsible for natural places with protecting the environment, as well as the welfare of the local population.

This research will design a model of tourism development to identify the real problems in the field that are expected to create a model that provides the benefits of tourism development for local communities with quality of life, the benefits for service providers or business tourism with the quality of opportunity and benefits for tourists that quality of experience.

\section{Methodological Framework}

\subsection{The Theoretical Framework}

\subsubsection{Tourism Supply and Demand}

In relation to the factors that determine the tourists to buy or visiting attractions. Medlik 1980 and Ariyanto 2005, stated that there are five factors that determine a person to buy services or visiting attractions, namely : ( 1 ) location , (2) the facilities, ( 3 ) the image / images , ( 4 ) price, ( 5 ) services.

\subsubsection{Alternative Tourism}

Grosclaude (2009) said that alternative tourism is tourism that offers a different way of traveling. Alternative tourism related to sustainable tourism, environmental tourism, community-based tourism and cultural tourism. Developing alternative tourism involvement, awareness and responsibility towards stakeholders.

\subsubsection{Blue Tourism Concept}

Blue Tourism is a term used by researchers in clarifying a concept-based nautical or maritime. This concept is the development of the concept of ecotourism which is one of environmentally friendly tourism activities with emphasis on aspects of nature conservation, social and cultural aspects of the economic empowerment of local communities as well as aspects of learning and education. According to TIES (The Ecotourism Society International, 1990) that defines ecotourism as a responsible travel to the place with the natural environment by preserving and improving the welfare of local residents. But Blue Tourism prefer the maritime or coastal natural resources as tourism objects to develop attractions (marine biology, marine transportation, marine recreation) and still offer aspects of learning and environmental conservation.

\subsubsection{Quality of Life, Quality of Opportunity and Quality of Experience}

The development of tourism region have to contain one of the principles of sustainability, to attain of the three qualities that tourism should be able to realize the quality of life of local communities, on the other hand must be able to provide quality tourism seeks quality of opportunity to service providers in the industry tourism and the next side and become the most important is the creation of quality tourist experience (United Nation 2002).

\subsection{Methodological Framework}

This research is a qualitative research with an emphasis on enrichment in the field. Location of the study are of Belitung 
Island Belitung and East Belitung. Data was collected through observation, depth interviews, literature review and documentation. Technical analysis of the data according to qualitative research, according to Miles and Huberman (1992), in qualitative research there are three activities that reduce the data flow, data presentation and conclusion. The data obtained by the mapping and identification of further analyzed using SWOT analysis and GAP analysis.

\subsubsection{SWOT Analysis}

One of analysis in this research is the analysis of SWOT (Strength, Weakness, Opportunity, and Threath). SWOT analysis can be simply understood as an instrument or device that is designed and used as an initial step in the process of modeling and decision by looking at four different sides that maximizes the power factor, take advantage of existing opportunities, minimize weaknesses and minimize the impact of emerging threats and to be faced .

\subsubsection{Gap Analysis}

The second analysis used is the Gap analysis which is doing a comparison of actual performance with potential or expected performance. This method is an evaluation tool that focuses on the current performance gap with previously targeted performance, such as those already listed in the work plan for each function. Gap analysis also identifies what actons are needed to reduce the gap or achieve the expected performance in the future.

\section{Results and Discussion}

\subsection{SWOT Analysis and Gap Analysis}

Observations and interviews were conducted with respondents, tourists, local governments, businesses and communities around the tourist attractions, resulting in a SWOT analysis in figure1.

From the SWOT analysis in diagram 1, we can developing the blue tourism strategy as follows:

1. Strength Opportunities (SO): Utilize the power maximumly to get the chance.

- Increasing the role of government, business tourism and maritime communities to develop tourism in line with the central government's plan.

- Promoting the regulation and supervision of coastal natural conditions in order to stay maintained and sustainable.

- The help from the local government to the people around the area.

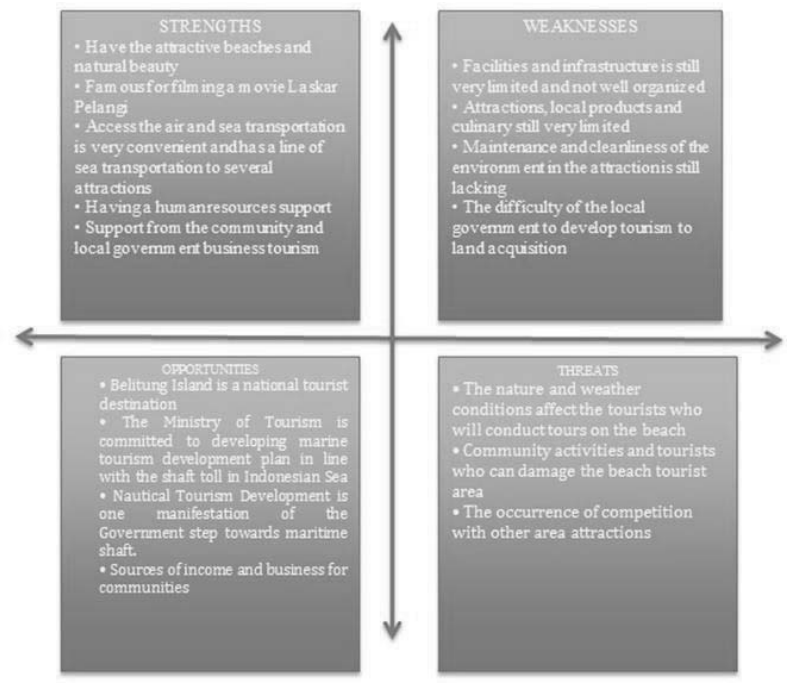

Figure 1. SWOT Analysis Touris in Belitung Island 
2. Weakness Opportunities (WO): Minimize the weakness to get the opportunities

- As a national tourist destination, it is necessary to improve the facilities and infrastructure to supporting the tourism

- Improve and held the attractions of tourism related to marine tourism, such as marine recreation, marine biology, and marine sports.

- Provide a learning center or information about the marine ecosystem on the island of Belitung such as: turtle, coral reef, reef fish, starfish and other

- The government gives an opportunity to the public in the form of container in building small businesses around the area of the beach as a place to eat that is comfortable and affordable accommodation for all.

- Do a maximum promotion of tourism development concept of blue tourism.

3. Threat Strength (ST): Optimization power to anticipate threats, and tried to make it as an opportunity.

- The existence of coordination and cooperation between communities, government and business tourism to maintain the security, hygiene and sustainability of the tourism area.

- Promoting good atmosphere around the tourism area, so it's memorable and make the tourist eager to repeat their visit

- Doing innovation and renewal of the attractions as well as supporting advice so it can compete with other regional tourist destinations

4. Weakness Threat (WT): Minimize weakness to avoid the threat.

- Promoting public awareness and knowledge as well as tourists in maintaining and preserving natural resources, such as by making a poster about the direction of preserving the ecosystem around the area.

- Conduct regional spatial planning according to conservation principles so it's safe, comfortable and does not disturb the environment

- Promoting the regulations for the preservation of the region.

After further analysis, SWOT analysis, GAP researchers aimed to look at the current state, see the GAP is happening and expect the desired conditions in the future. GAP anlysis in this study as follows:

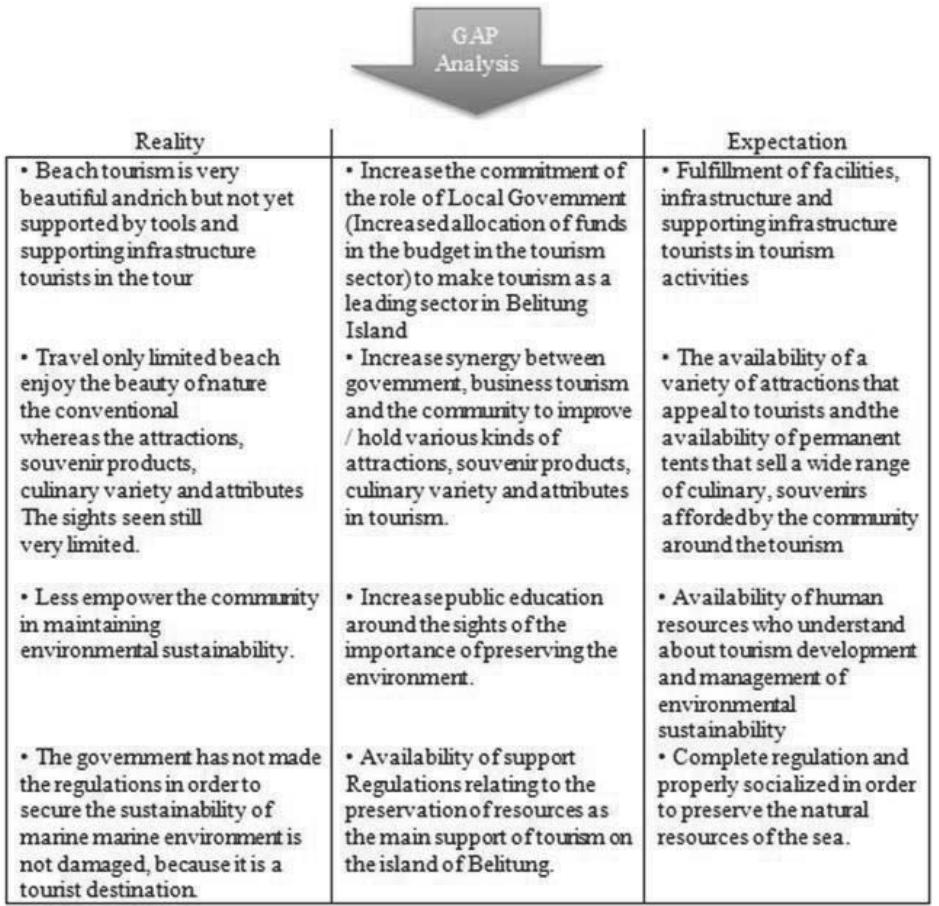

Figure 2. GAP Analysis Tourism in Belitung Island 
From the GAP Analysis diagram, it appears that to close the gaps between the reality with the expected, then there are several things that must be done so that the blue tourism can be implemented on Belitung Island such as :

1. A strong commitment from local governments, businesses and the public to make the tourism sector as the leading sector of blue tourism with an optimal funding.

2. To coordinate between regions and the association of nautical tourism as an input for the development of tourism on Belitung island.

3. Provide the socialization rules and regulation to maintain the marine environment, because it is a tourist destination and is a potential area that must be maintained sustainability.

4. Perform housekeeping facilities, infrastructure, and human resources supporting with effective and efficient.

\section{Blue Tourism Model Development}

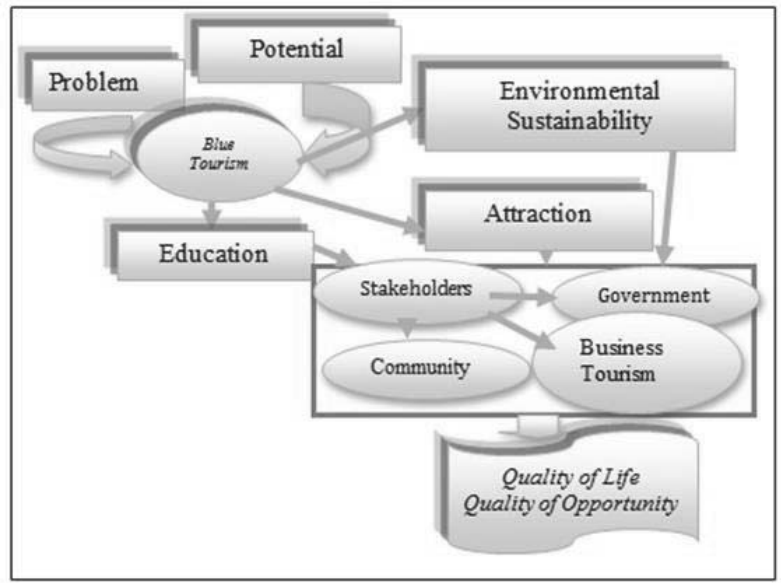

Figure 3. Blue Tourism Model

From the model of the development of blue tourism in Belitung Island, can be explained that the tourism development concept start from the problems and the potential that exists on the Belitung island. This development model have the alternative, they are learning, attractions and preservation of the environment, which could be an option for tourists in order to reach the desired traveled quality (Quality Of Life, Quality Of Opportunity and Quality Of Experience). Implementation and successful application of the model is dependent upon the commitment of the stakeholders in this case are local government, private and public.

Kurniawan (2010), Lewarherilla (2006), argued that the development of a marine tourism area will succeed if development is associated with an institution or agency management, namely local governments, private and public. We expected with this model will have a positive impact for the local government which is to achieve an effort to make tourism a mainstay sector mainly blue marine tourism concept of tourism and increase the number of tourist arrivals, while the private sector is increasing the amount of economic activity in the tourism sector which resulted in an increase income and able to absorb the labor force and the community can play an active role in the tourism sector in accordance with the capabilities. The model has been applied attempted sustainability so that it can provide benefits to local communities, businesses and tourists travel with quality of life, quality of opportunity and quality of experience.

\section{Conclusion}

The conclusion of this research are:

- Blue Tourism is tourism development concept that promotes maritime or coastal natural resources as tourism objects to develop attractions (marine biology, marine transportation, marine recreation) and still offer aspects of learning and environmental conservation.

- Efforts is needed to optimalize the development from the stakeholders as well as inter-regional cooperation 
and maritime tourism associations.

- It's a need to set the regulation of the sea in order to secure the preservation of the marine environment

- Sustainability of tourism development with blue concept of tourism could benefit local communities, businesses and tourists travel with quality of life, quality of opportunity and quality of experience.

- For the further research, it is recommended to tries to examine the quality of life, quality of opportunity and quality of experience quantitatively.

\section{References}

Andriani, Pitana (2011). Ecotourism: Theory, Application, Implication. Jurnal Kepariwisataan Indonesia 6.119 - 132.

Ariyanto. 2005. Ekonomi Pariwisata. http://www.geocities.com/ariyanto eks79/home.htm

Baiquni M (2011). Alternative Tourism in Yogyakarta. Jurnal Kepariwisataan Indonesia 6.133 - 145

Burkart, A.Jdan Medlik, S.1981. Tourism Past, Present nad Future. London: Heinman

Department of Culture and Tourism, Bangka Belitung Province. Tourism Potential in Belitung Island (2014)

Grosclaude, Laurent (2009). Trend in Alternative Tourism: idea, discussion and experience. Translated Journal in Starting the Alternative Tourism's Seminar in Institute of Indonesia-France.

Kurniawan R, (2010). Sustainable Karst Management System in Maros Pangkep, South Sulawesi Province (Disertation), Bogor: Institut Pertanian Bogor.

Lewarherilla, NE (2006). Regulation Analysis of Youtefa Bay's Management in Jayapura (Disertation), Bogor: Institut Pertanian Bogor.

Macleod, Donald V.L (2006). Alternatif Tourism: a comparative analysis of meaning impact.

Miles, Huberman (1992). Qualitative Data Analysis. UI Press Jakarta

United Nations Population Division. World population prospects: The 2002 Revision. New York: United Nations; 2003

The International Ecotourism Society (TIES) (1990), What is Ecotourism?: Principles of Ecotourism 